\title{
Critical Thinking Skills: British Parliamentary Debate System to Improve English as Foreign Language (EFL) Students' Critical Speaking
}

\author{
Sri Wahyuni ${ }^{1}$, Hijjatul Qamariah ${ }^{1}$, Sofyan A.Gani ${ }^{2}$, Yunisrina Qismullah Yusuf ${ }^{2}$, \\ Mulyadi Syahputra ${ }^{1}$ \\ ${ }^{I}$ Department of English Education, Teacher Training and Education of STKIP Bina Bangsa Getsempena, Banda \\ Aceh, Indonesia \\ ${ }^{2}$ Department of English Education, Faculty of Teacher Training and Education, Universitas Syiah Kuala, \\ Banda Aceh, Indonesia \\ sri.wahyuni.sw837@gmail.com
}

\begin{abstract}
Debate as one of techniques in teaching speaking has been believed can accommodate and facilitate teachers in improving students speaking skill. It is also believed that students' critical thinking can be ignited though debate technique. This research, therefore would like to employ the debate technique of British parliamentary system in teaching speaking in order to initiate students critical thinking. This is a quantitative research by applying experimental method. The population of this study was English speaking class in private Higher Education (PTS) in Aceh and the sample were two English speaking classes in Private Higher Education in Aceh. The sample, however, were two English speaking classes in Private Higher Education in Aceh. The data of this study were gained from pre test and post test, thus the results of the test were then analyzed though statistic formula. From the analyzed data, it was showed that in sample 1, the t table was 2.145 and $t$-test was 6.006, in sample 2 the t table was 2.228 and t-test was 2.936. The research finding revealed that, the t-test found was higher than t-table. It can be concluded that $\mathrm{Ho}$ in the study was rejected that there was an improvement on students' critical thinking skill after applying the British Parliamentary debate system.
\end{abstract}

Keywords : debate technique; speaking skills; critical thinking; british parliamentary system

\section{Introduction}

Speaking as EFL is demanded to belearnedbyall of the learners. Itisaparticularway to express an idea to other people, speak without stuttering and establish the unbiased instruction during a communication. Speakingisa pleasant activity not only due to the ease of using it in extending, sharing and collaborating with others but also to the chance of individuals, particularly students, to communicate with English native or non-native speaker.Therefore, in everyday's life, everyone has to be able to communicate in oral form in order to involve into an interaction among people around. Moreover, it is an indirect form of obligation for any individuals to master speaking skill for their purpose to establish a social relationship among the society which is very essential in life.As stated by Brown (2004:140), speaking is a productive skill that can be observed directly and empirically. Moreover, speaking is a way to interact by using language in an oral production to share or express ideas, to discuss or establish friendships. So, speaking can be measured empirically when the process of sending information is done effectively.

Mastering speaking skill is complex. It is not only about expressing the idea but also ensuring the interlocutors understand about the point that has been delivered through the various signals given by the interlocutors during the speaking such as nodding, facial expression, and also eyes movement. Moreover, the speakers are required to have clear 
pronunciation, numbers of vocabularies and fluency to ease the process of transferring the information to the listeners.

In addition, speaking skill requires the listening ability at the same time to support the process of transferring and receiving the message. Both skills should be mastered well by the speakers because speaking has a wide range of possible response that could not be predicted hence the way to have effective communication is by listening and responding.

Critical speaking skill problem is beyond the language boundary. Iskandar (2009) argued that the ability to think is the reasoning activity that carried out in all of a sudden or reflexively, critically, creatively, and oriented to the process of thought which is resulted in establishing the concept. The challenge among students in being critical is not merely the language but also the capacity of the individual to evaluate and associate the evidence.Subsequently, the critical speaking brings a new challenge for students to master the ability to evaluate and associate the evidence as well as to pack the information with some various type of vocabulary which is uttered with clear pronunciation and also a fluent flow of the speaking itself.

Regardless of the issues above, students are expected to be able to use English in speaking subject as well as to improve their ability in critical speaking. That is why the solution to these challenges is urgently needed to be discovered. However, to cover higher students critical thinking issue in improving their speaking skill, the lecturer should be able to select the most appropriate technique to those demands. There are some classroom speaking activitiesthat can be either respectively or collectively used by a lecturerin the teaching-learningprocess, such as storytelling, group discussion, role play, and debate. The debateis one of the techniques that can be used in teaching English speaking in order to improve students speaking skill.

The debate is speaking situation that pushes students $t$ othink critically in multiple perspective sofanissue.The goal of the debate is to persuade judges tobelieve $n$ all of the statements given. Maryadi(2008:16) stated that debate can motivatestudents'to think, andtheyshould defendtheirstandor opinionwhichis aimed to convinceother individuals. The debate can be used in EFL classes as a tool to make student spractice their skills in speaking the English language inareal setting. The procedure of debate involved the speaking and listening skill for instance, while a speaker delivers his/her substantive speech the other listens to it. This technique is effective to give them chance to share ideas and thoughts infront of audiences with the formal setting. Besides this technique is also the potential to disappear students nervousness during speaking. Nesbett (2003:210 )statedthatdebate isan important educational tool for learning analytical thinking skillas well as for forcingself-conscious reflection on th evalidity of one'sidea.

One of the common systems used in the debate is parliamentary debate such as British, Asia, Australian, and other formats. British Parliamentary System is the debate parliamentary system which is used universally by universities in Indonesia. This system includes 8 people consisting of 4 teams with different sides of arguments (pros and cons). British Parliamentary System is a Parliamentary debate which is a debate held in a parliamentary session in England and officially adopted as the debate format used in WUDC (World University Debating Competition). The use of this parliamentary system in the educational context is unpopular. That is why it needs to investigate further on the effectivity of the system to improve students' critical speaking ability.

Based on the background above, the writer formulated the research question as follow: Does the use of British Parliamentary debate system improve students' critical thinking in speaking skill? 


\section{Methodology}

The population in this research was the private higher education in Aceh that has English Education Department. The reason behind this decision was that the number of critical thinking ability in theprivate university in Aceh was still low due to the lower position of National University Debating Championship that annually been conducted byCoordinator of Private Universities Region XII (Kopertis XIII) one of the debate tournament that standardizes the critical thinking ability of the participants.

The sample of the research was Abulyatama University, Aceh Besar and Al-Muslim University Bireun. The sample was selected purposely based on the result of National University Debating Championship (NUDC) 2018 which shows both universities achieved better rank among other private universities in Regional Circuit. The researcher used a quasiexperimental study which pre-test, treatment, and post-test were applied to the same group to analyze the groups' improvement.

The instrument used in this research was the test which divided into pre-test and posttest. 25 questions were given to the participant to assess their ability in identifying, constructing, evaluating arguments and solving problems given during the debate.

\section{Discussion}

The research was aimed to investigate the improvement of students' critical thinking after applying debate technique using British Parliamentary System. The samples were given pretest, 7 sessions of treatments that underdone in 4 days and post-test. The result was presented in form of quantitative based on the pre-test and post-test result. The result was analyzed using SPSS (Statistical Product and Service Solution) 24.0 for Windows. The data in both samples were analyzed as table follow.

Table 1. The summary of the T-test Table in sample 1

\begin{tabular}{r|rr} 
Type of data & Pre-test & Post-test \\
Mean & 60.38461538 & 67.84615 \\
Variance & 2.08974359 & 17.97436 \\
Observations & 13 & 13 \\
Pooled Variance & 10.03205128 & \\
Hypothesized Mean Difference & 0 & \\
$d f$ & 24 \\
t-test & -6.00606722 & \\
$P(T<=t)$ one-tail & $1.67843 \mathrm{E}-06$ & \\
$t$ Critical one-tail & 1.71088208 & \\
$P(T<=t)$ two-tail & $3.35686 \mathrm{E}-06$ & \\
$t$ Critical two-tail & 2.063898562 & \\
Degree of freedom $=0,05$ &
\end{tabular}


Table 2. The summary of the T-test Table in sample 2

\begin{tabular}{r|rr}
\multicolumn{1}{r}{ Type of data } & \multicolumn{1}{c}{ Pre-test } & Post-test \\
\hline Mean & 60.3 & 62.2 \\
Variance & 2.677777778 & 1.511111111 \\
Observations & 10 & 10 \\
Pooled Variance & 2.094444444 & \\
$d f$ & 0 & \\
Hypothesized Mean Difference & 18 & \\
t-test & -2.935649355 & \\
$P(T<=t)$ one-tail & 0.004418579 & \\
$t$ Critical one-tail & 1.734063592 & \\
$P(T<=t)$ two-tail & 0.008837159 & \\
$t$ Critical two-tail & 2.100922037 &
\end{tabular}

Degree of Freedom $=0,05$

From the tables above, we can conclude that the number oft tablein the first sample is 2.160 which is less than thet $t_{\text {test }} 6.006$. While the number of $t_{\text {tablein }}$ the second sample is 1.987 which is also less than the number of $t_{\text {test }} 2.936$. However, based on the test criteria for a test that if $t_{\text {test }} \leq t_{\text {tabel }}$ it means that Ho is accepted. On the other hand, if $t_{\text {test }}>t_{\text {tableit means that Ho is rejected }}$

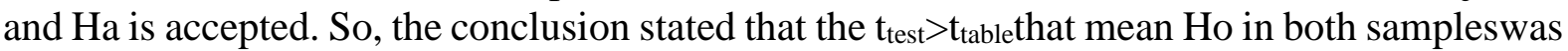
rejected and Ha was accepted. It can be interpreted that the students' skill in critical thinking has improved after applying the debate technique using British Parliamentary System in both samples.

Meanwhile, the hypothesis on the significance test was as follow.

$\mathrm{H}_{0}$ :the students' critical thinking ability did not improve after applying debate technique using British parliamentary debate system

$\mathrm{H}_{1}$ :the students' critical thinking ability improved after applying debate technique using BritishParliamentary Debate system

The criteria for assessing the significance-test based on $t_{\text {tableare }} 1$ ) if the level of significance degree $>0,05$ then Ho is accepted. and, 2). if the level of significance degree $\leq$ 0,05 then $\mathrm{Ho}$ is rejected/ $\mathrm{Ha}$ is accepted.After assessing the data, it was found that the level of significance degree $(\mathrm{sg})$ in the first sample is 0.000 and 0.004 in the second sample. Hence, in the first sample, $0.000<0,05$ and in the second sample $0.004<0,05$ which showed that the level significance in both samples were less than 0,05 , so, Ho is rejected in both samples. The result can be interpreted that there is a significant difference in the students' critical thinking skill after applying debate technique using British Parliamentary System in both samples.

\section{Conclusion}

Based on the data above, the conclusion can be drawn that the use of debate technique with British Parliamentary System is effective to increase students' critical thinking skill in private higher education students. Moreover, the use of this technique is highly recommended for lectures to increase students' critical thinking especially in the area of speaking. British 
Parliamentary System still needs further development in many areas, so that it can be adapted to the learning needs with a much greater participation and complexity of the material adjustments that are much higher than just discussing the current issues randomly.

\section{Acknowledgement}

The writers would like to express their gratitude to KEMENRISTEK DIKTI for the support, thus this research can be conducted. Their gratitude also expressed to STKIP Bina Bangsa Getsempena which provides this valuable chance so the writers can participate in the competitive and important research scheme. The appreciation is also given to Dr. Sofyan A. gani and Dr. Yunisrina Qismullah Yusuf from Syiah Kuala University for becoming research team in finishing this research.

\section{References}

Arung, F. (2016).Journal of English Education (JEE). Vol.1, No.1 March 2016. P-ISSN: 25029207. E-ISSN : 2502-6909. URL: http//usnsj.com/index.php/JEE/. USN Scientific Jpurnal Publisher, Universitas Sembilan belas November Kolaka.

Brown, H. D. (2004). Language Assessment: Principles and Classroom Practices, New York: Pearson Education.

Brown, Z. (2015). Educational futures.e-journal of the British Education Studies Assosiation. Vol.7 (1) January 2015. ISSN:1758-2199.BESA.

Cameron, L. (2001). Teaching Language toYoung Leaners. Cambridge: Cambridge University Press

Freeley. A. A., \& Steinberg. D., L (2009). Argumentation \& Debate, Critical Thinking for Reasoned Decision making. Wadsworth Cengage Learning. New York

Iskandar (2009).Penelitian Pendidikandan Sosial.Jakarta: Gaung Persada Press

Iskandar. (2009). Metodologi Penelitian Pendidikan dan Sosial. Jakarta: Gaung Persada Press. Johnson, S. P. (2003). The Nature of Cognitive Development. Trends in Cognitive Sciences, 7(3).

Mason, M. (2007). Critical thinking and learning.Educational Philosophy \& Theory, 39, 339349. http://dx.doi.org/10.1111/j.1469-5812.2007.00343.x

Krieger, D. 2005. Teaching Debateto EFL Students:AsixUnit.TheInternet Journal

Luoma, S. (2004). Assessing Speaking. Cambridge: Cambridge University Press.

Maryadi,A. (2008). Implementing Debate In School.Jakarta:RinekaCipta

Morrow, D. R. \& Weston, A (2011). A workbook for Arguments, A Complete Course in Critical Thinking. Hackett Publishing Company, Inc; Indianapolis

Nisbett.(2003). The Geography of thought.NewYork:TheFreePress

Nunan, D. (2001). Research Methods in Language Learning. Cambridge: Cambridge

Nunan, David. (2003). Practical English Language Teaching. New York: McGraw-Hill

Smith, N. H.(2011). The Practicalto Guide to Debating World Style/British Parliamentary style.IDEA:New York, London \& Amsterdam

Thornbury,S. (2005). How To Teach Speaking.England: Longman

Wijaya, S. A. (2016). Register Journal. Language \& Language Teaching Journals.Vol 9, No 2. P-ISSN : 1979-8903, E-ISSN : 2503-040x. English Education Department, State Institute for Islamic Studies (IAIN) Salatiga, Indonesia. 